\title{
MANURE MANAGEMENT, QUALITY AND MINERALIZTION FOR SUSTAINING SMALLHOLDER LIVELIHOODS IN THE UPPER EAST REGION OF GHANA
}

\author{
J. O. Fening ${ }^{1 *}$, T. Adjei-Gyapong ${ }^{2}$, N. Ewusi-Mensah ${ }^{2}$ and E. Y. Safo ${ }^{2}$. \\ ${ }^{1}$ Soil Research Institute Academy Post PMB Kwadaso Kumasi, Ghana \\ ${ }^{2}$ Dept of Crop Science, Faculty of Agric. KNUST. Kumasi, \\ *Corresponding author (kofifening@yahoo.com)
}

\begin{abstract}
A survey was conducted in the Upper East region of Ghana to seek information on the fertility status of the soils, manure production, its management options and nutrient concentration that could be associated with quality. Analysis of soils from farmers' fields showed that the soils are coarse textured, with low exchange capacity and organic matter contents. Available $P$ in particular was very low with most of the soils having values less than $6.00 \mathrm{ppm}$. Four main types of cattle rearing systems were encountered; the field, kraal, compound and intensive. Fresh manure samples from each of these systems were collected air dried and analysed in the laboratory using standard protocols. The $N$ and $P$ contents of the manure ranged from $0.52 \%$ to $1.14 \%$, and 0.28 $\%$ to $0.76 \%$ respectively, which were below the critical levels for net mineralization. Polyphenol contents on the other hand were lower than the critical value of $4 \%$. Decomposition and nutrient release of the manure showed immobilization of total $N$ during the first four weeks, suggesting the need to improve the quality by composting or applying it in combination with mineral fertilizers.
\end{abstract}

Keywords: Crop production, fertilizer value, nutrient release, soil fertility.

\section{INTRODUCTION}

The Upper East Region of Ghana covers a total land area of $8,842 \mathrm{~km}^{2}$ with a population of 917,251(Macmillan, 2001), which is $87 \%$ rural (MoFA, 2001). It is the most densely cattle rearing region and the second most human populated region. The mainstay of livelihood for sustaining the ever-increasing population is agriculture which is severely constrained by soil degradation. Large tracks of agricultural land have been rendered unproductive causing increased food insecurity, reduction in farm incomes, limited returns from agricultural in- vestment and rural poverty. The result of this is the steady southward migration of people from the region to urban centres in search of jobs to sustain their livelihoods.

Small holder farmers in the region have over time found widespread use of cattle manure for improving the fertility status of their crop lands. Crop yields are however, very low (MoFA, 2001), suggestive of numerous constraints facing farmers in the management of manure for crop production. Many crop response trials have looked at rates and methods of manure 
application, effects on soil chemical and physical properties and effects on soil moisture dynamics. What these trials have lacked is that they have not considered the different factors that affect the quality of the manure, which is related to the decomposition and nutrient release rates and patterns (Pettygrove and Heinrich, 2009; Janssen, 1993). In order to optimize manure quality, proper knowledge is required for manure collection, storage and utilization that would minimize nutrient loss and allow the nutrients to be available to the crops. The objectives of this paper were: (1) to seek information on practices likely to influence manure quality and (2) determine nutrient supplying capacity of manure found in the region.

\section{MATERIALS AND METHODS}

Three hundred farmers were interviewed using structured questionnaires. The survey sought information on practices likely to influence (i) cattle management including population, breed, animal housing, (ii) manure management including quantity, collection, handling, storage, treatment prior to utilization, (iii) manure application including crop yield. Field observations and interview with key informants such as extension officers and local leaders were also conducted using a check list to supplement the questionnaire.

Four main types of cattle rearing systems were encountered during the survey. These were, (1) the field system where the animals graze freely in the range, moving from one place to another without any housing, (2) the kraal system in which animals are tethered to $\operatorname{logs}$ near the household compound to graze, (3) the compound system where mud is used to build a fence for housing the animals. The animals graze in the range during the day and are brought into the fence at night, (4) the intensive systems where roofing housing units are built to house and feed the animals. Farmers in the region apply manure in the dry state by surface broadcasting and ploughing into the soil, manually. Approximately $5 \mathrm{~kg}$ of fresh manure was collected randomly from each of these systems and taken to the Soil Research Institute laboratory where it was air dried and ground to pass through a $2 \mathrm{~mm}$ sieve. Samples were digested with concentrated sulphuric acid (Anderson and Ingram, 1993). Total $\mathrm{N}$ and $\mathrm{P}$ were determined colorimetrically (Parkinson and Allen, 1975), ammonium and nitrate $\mathrm{N}$ (Bremmner and Keeney, 1965) and K by flame photometry. Calcium and $\mathrm{Mg}$ were estimated using the procedure of Anderson and Ingram (1993). Organic carbon was determined by the WalkleyBlack method (1934). Polyphenol content was determined by the Folin - Denis reagent method (Constantinides and Fownes, 1994). Soil samples were also taken randomly from some farmers' fields. On each farm ten core samples were taken with galvanized iron cores $4.5 \mathrm{~cm}$ inner diameter and $25 \mathrm{~cm}$ high. The core was gently hammered into the soil and the content emptied into plastic buckets. The content of the bucket per field (multiple points of 10 cores) was thoroughly mixed and sub samples were taken to the laboratory. Soil $(\mathrm{pH})$, organic carbon, total nitrogen, available $\mathrm{P}$, potassium, and exchangeable cations were determined on the soil samples using standard protocols (Ingram and Anderson, 1993). Particle Size analysis was determined by the pipette method (Gee and Bauder, 1986).

Nitrogen mineralization from the manure was determined by the leaching tube incubation method (Giller, 1999). The leaching solution contained $1 \mathrm{mM} \mathrm{CaCl}{ }_{2} ; 1 \mathrm{mM} \mathrm{MgSO}_{4} ; 0.1$ $\mathrm{mM} \mathrm{KH} \mathrm{PO}_{4}$ and $0.9 \mathrm{mM} \mathrm{KC1}$ (Giller 1999). Prior to mineral $\mathrm{N}$ determination, manure was ground and applied at a rate equivalent to 100 mg $\mathrm{N} \mathrm{kg}^{-1}$ soil following initial total $\mathrm{N}$ and $\mathrm{C}$ analyses. The manure was mixed with $150 \mathrm{~g}$ soil (2:1 soil: sand mixture). Leaching was done with $120 \mathrm{ml}$ of leaching solution in $3 \times 40$ ml aliquots. The initial $\mathrm{NH}_{4}{ }^{+} \mathrm{N}$ and $\mathrm{NO}_{3}{ }^{-}-\mathrm{N}$ for all treatments were analysed from leachates collected on day 0 . The tubes were subsequently leached on days $7,14,21,28,35,42$, 49 and 56. The tubes were incubated in the dark at $28^{\circ} \mathrm{C}$, and excess water following each 
leaching event was removed by a mild suction pump. The leachates were analysed for $\mathrm{NH}_{4}{ }^{+}-$ $\mathrm{N}$ and $\mathrm{NO}_{3}{ }^{-}-\mathrm{N}$. Net $\mathrm{N}$ mineralization was calculated as the difference between the $\mathrm{N}$ released from the amended test samples and that of the unamended control. Carbon mineralization was estimated by $10 \mathrm{ml}$ of $0.1 \mathrm{M} \mathrm{NaOH}$ trap contained in small vials hung from the top of each sealed leaching tube (Stotzky 1965). The amount of trapped $\mathrm{CO}_{2}$ was determined by back titration using $0.1 \mathrm{M} \mathrm{HC1}$ and phenolphthalein indicator $(0.5 \%)$ at intervals of 7,14 , $21,28,35,42,49$ and 56 days. Two to three drops of $1.0 \mathrm{M} \mathrm{BaCl}_{2}$ were added to each vial to stabilise the trapped $\mathrm{CO}_{2}$ as $\mathrm{CO}_{3}{ }^{-}$before titration. The amount of trapped $\mathrm{CO}_{2^{-}} \mathrm{C}$ was calculated as follows:

$\operatorname{mg~} \mathrm{CO}_{2}-\mathrm{C}=$

(ml HC1 blank - $\mathrm{ml} \mathrm{HCl} \mathrm{sample)} \mathrm{x} M$ x 22

Sample weight (mg)

Where: $M=$ Molarity of $\mathrm{HCl}$

$22=$ the equivalent weight of $\mathrm{CO}_{2}$

\section{RESULTS AND DISCUSSIONS}

The physical and chemical characteristics of the soils are presented in Table 1 . The levels measured and/or calculated have been ranked according to classes described by FAO (1984) for soil reaction (degree of acidity): Landen (1991) for $\mathrm{Mg}$ (low to high) Arcia et al. (1995) for the other parameters (low to high). The soil $\mathrm{pH}$ ranged from moderately acid to neutral $(\mathrm{pH} 5.3$ - 7.1) with majority of the soils being moderately acid to slightly acid typical of the Interior Savanna zone (Sys et al., 1993). Soil organic matter content ranged from $0.55 \%$ to $1.79 \%$ with a mean of $1.33 \%$. Total nitrogen levels ranged from $0.14 \%$ to $0.23 \%$ which were ranked medium. There was considerable variability in exchangeable basic cations of the soils. Exchangeable calcium $\left(\mathrm{Ca}^{++}\right)$ranged from low $(2.94 \mathrm{cmol}(+) / \mathrm{Kg}$ soil) to high (11.48 cmol $(+) / \mathrm{Kg}$ soil). Mean $\mathrm{Ca}^{++}$levels was ranked medium $(6.18 \mathrm{cmol}(+) / \mathrm{Kg}$ soil). Exchangeable $\mathrm{Mg}$ also ranged from low to high
(0.67 to $4.48 \mathrm{cmol}(+) / \mathrm{Kg}$ soil). Exchangeable potassium levels were similarly low to high $(0.15$ to $0.69 \mathrm{cmol}(+) / \mathrm{Kg}$ soil). The soils were generally coarse textured, dominantly sandy loam with very low clay contents (Table 1). The low organic matter contents may be due to high temperatures, resulting in rapid decomposition of organic materials and bush burning that make the soil bare. The variability in exchangeable basic cations on the other hand may be attributed to poor profile development. The soils are brashy with many pieces of green stone and upper Birimian rocks which weather to recharge the system.

Four main types of cattle rearing systems were encountered during the survey. Respondents cited manure production (84\%) and labour (7\%) as the main purposes for rearing cattle. Surprisingly only (4\%) of the total respondents reared cattle for meat. The systems encountered were: (i) the field system where animal graze freely in the range and their dung is deposited all over the field (ii) kraaling system in which animals are tethered to logs near the household compound and their location within the field shifted accordingly at certain time intervals. (iii) the compound system where mud is used to build a fence for housing the animals within the compound of the farmer. The animals graze in the range during the day and are brought into the fence at night. This system allows the dung to be collected and kept for use during the cropping season (iv) the intensive systems where roofing housing units are built to house and feed the animals. This system also allows the dung to be collected and the performance of each animal is also monitored. The housing units of the compound and kraal systems had no roofing, and the floors were bare ground soil with virtually no bedding materials. The manure is left unattended to or heaped beside the kraal as a continuous process. There was no system in place that allowed drainage of urine away or retained much. Most of the urinary $\mathrm{N}$ is leached down the soil and considerable amount of $\mathrm{N}$ is also lost via volatilization. During the wet season the soggy anaerobic condi- 


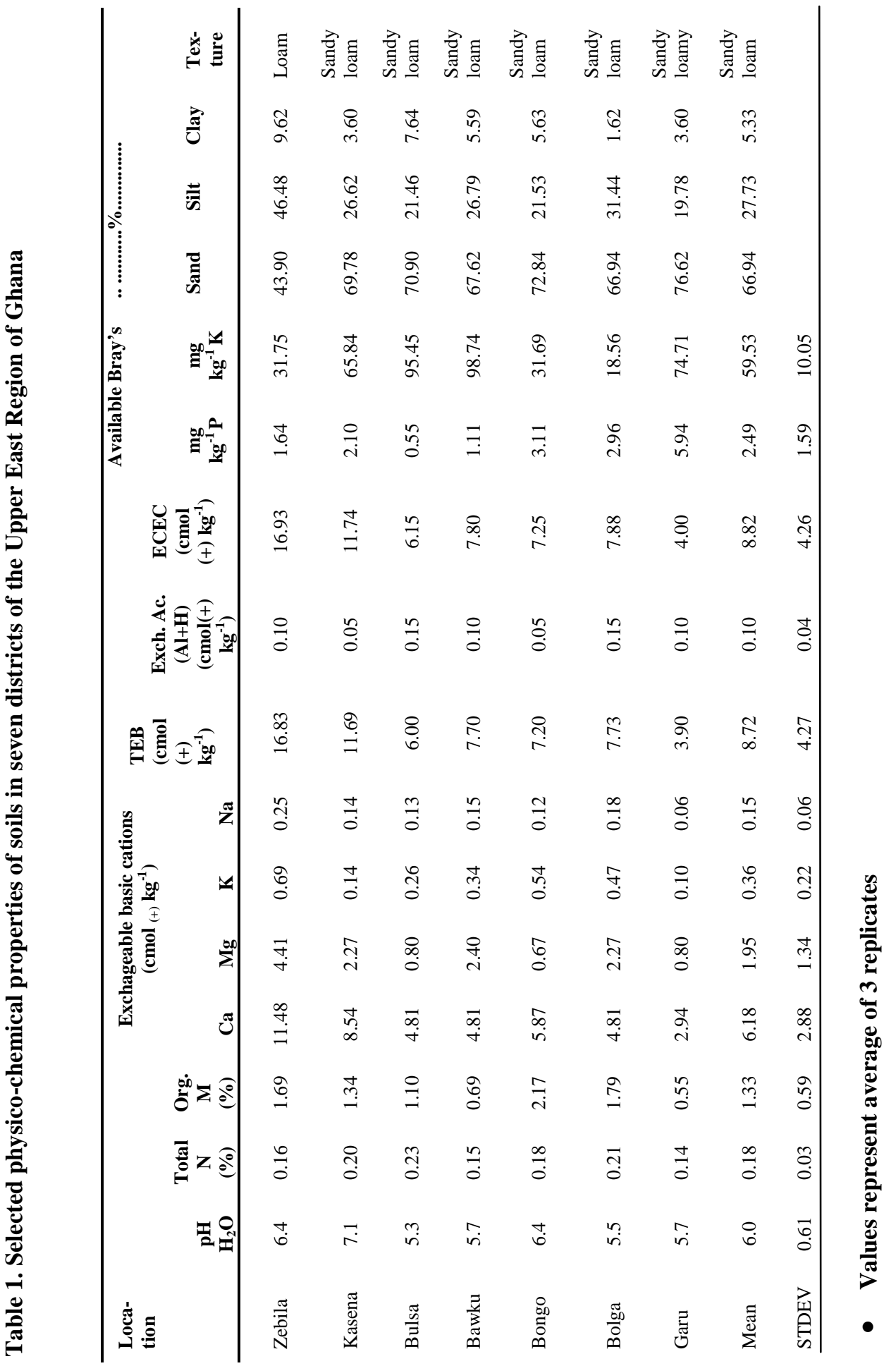


Manure Management, Quality and Mineralization... 5

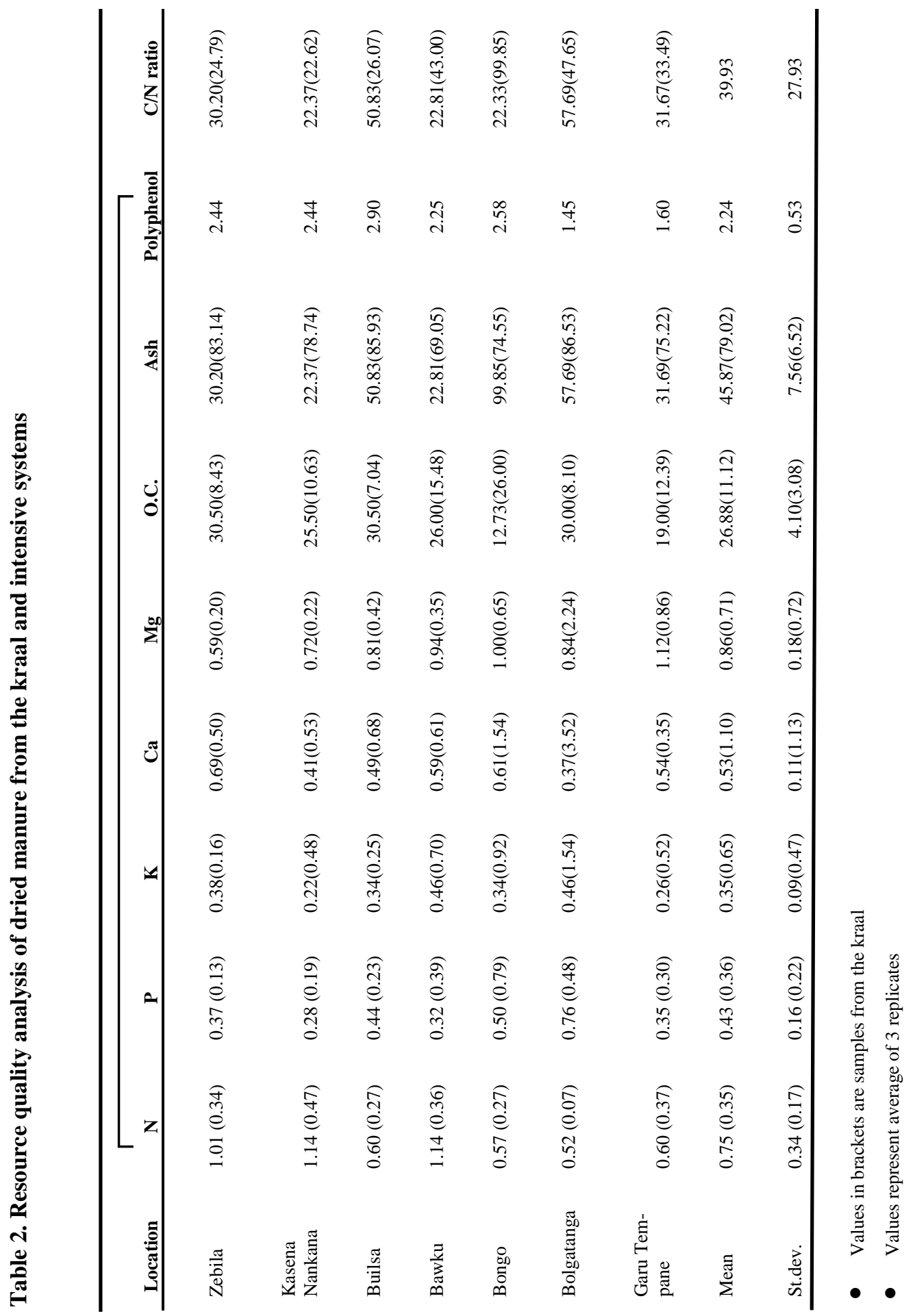


tions may result in denitrification which further affects the quality. Despite the alternative uses of cowdung in the region, $84 \%$ of the respondents ranked its application to crop fields as the main objective for rearing cattle. Giller (2009) similarly observed that small scale farmers in Kenya valued livestock manure and lessened the importance of livestock for traction. About $44 \%$ of the respondents used other types of manure apart from cowdung (manure from small ruminants, poultry and crop residues) whiles $36 \%$ applied mineral fertilizers in addition to cowdung on their fields.

Analysis of the manure samples collected showed that percent ash content was relatively high $(60 \%)$ in the heaped manure, due to mixing with soil from the floor during collection. The $\mathrm{N}$ content of the fresh manure was twice higher than the heaped and ranged from $0.27 \%$ to $1.14 \%$ (Table 2). Phosphorus content varied from a low value of $0.28 \%$ to $0.76 \%$. The low levels of $\mathrm{P}$ in the manure samples is an issue worth considering given that $\mathrm{P}$ is a primary limiting nutrient in the region. The $\mathrm{C} / \mathrm{N}$ ratio was above $20 \%$, which indicate potential or likely net immobilization but high organic matter contribution to the soil, which is considered an important extra benefit of using manure as a soil amendment (Mando et al., 2005). Another important modifier of nutrient release from organic materials is the polyphenol content.

The immobilization resulting from polyphenolics, may be much longer than temporary immobilization from high $\mathrm{C} / \mathrm{N}$ ratios (Giller et al., 1997). The manure samples collected however, had polyphenol contents that ranged from 1.45 $\%-2.90 \%$ lower than $4 \%$ which is the critical value proposed by Palm et al. (1997) on resource quality and nutrient release patterns of organic materials for net $\mathrm{N}$ mineralization. There was immobilization of $\mathrm{NH}_{4}, \mathrm{NO}_{3}$, and total $\mathrm{N}$ within the first two weeks of incubation followed by net mineralization which reached a peak level of above $1 \mathrm{mg} \mathrm{kg}^{-1}$ at 28 days after incubation (Figures 1, 2 and 3). Similar results were obtained in green house studies by Mugwira and Mukurumbira (1984), who reported a depression in maize grain yields in the first two weeks of planting in manure pots. Much longer periods of immobilization from cattle manure up to 105 days have been observed (Fauci and Pick, 1994), which contradicts the findings of Nhamo et al. (2004) who reported net $\mathrm{N}$ mineralization at the start of incubation.

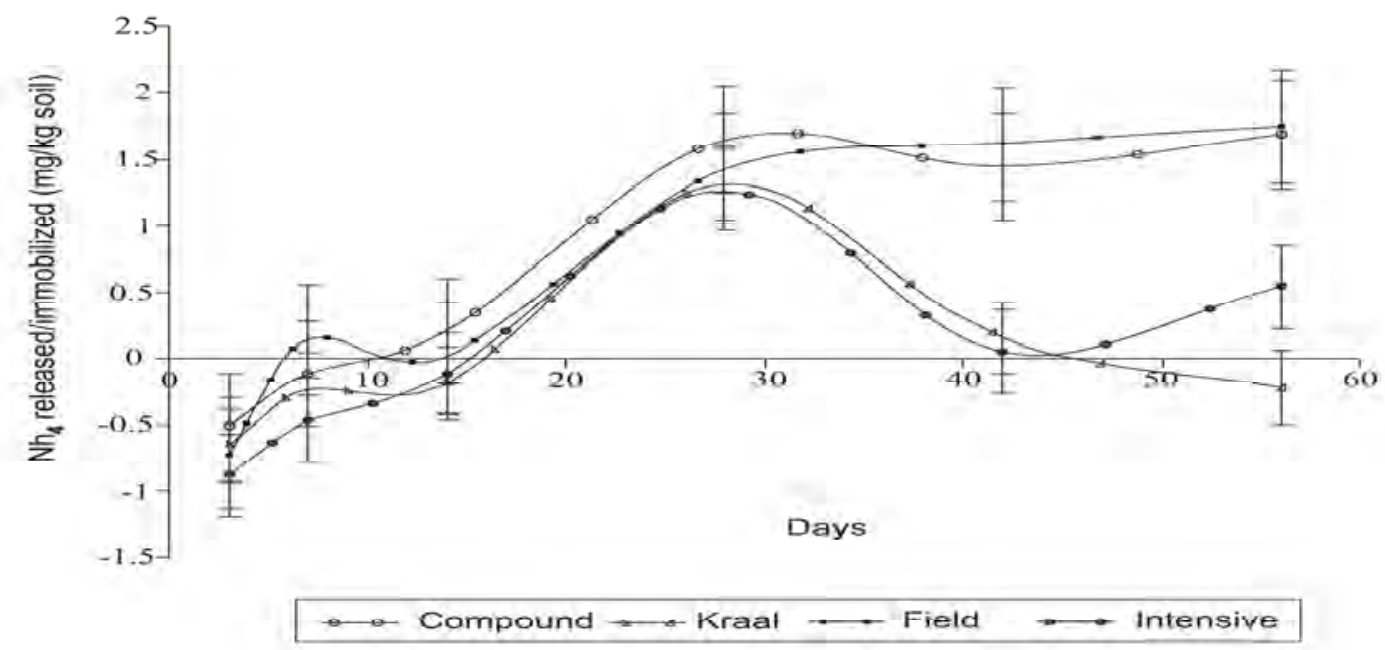

Figure 1. Amount of $\mathrm{NH}_{4}$ remaining at various stages of incubation. Bars indicate SED at $p=0.05$ 


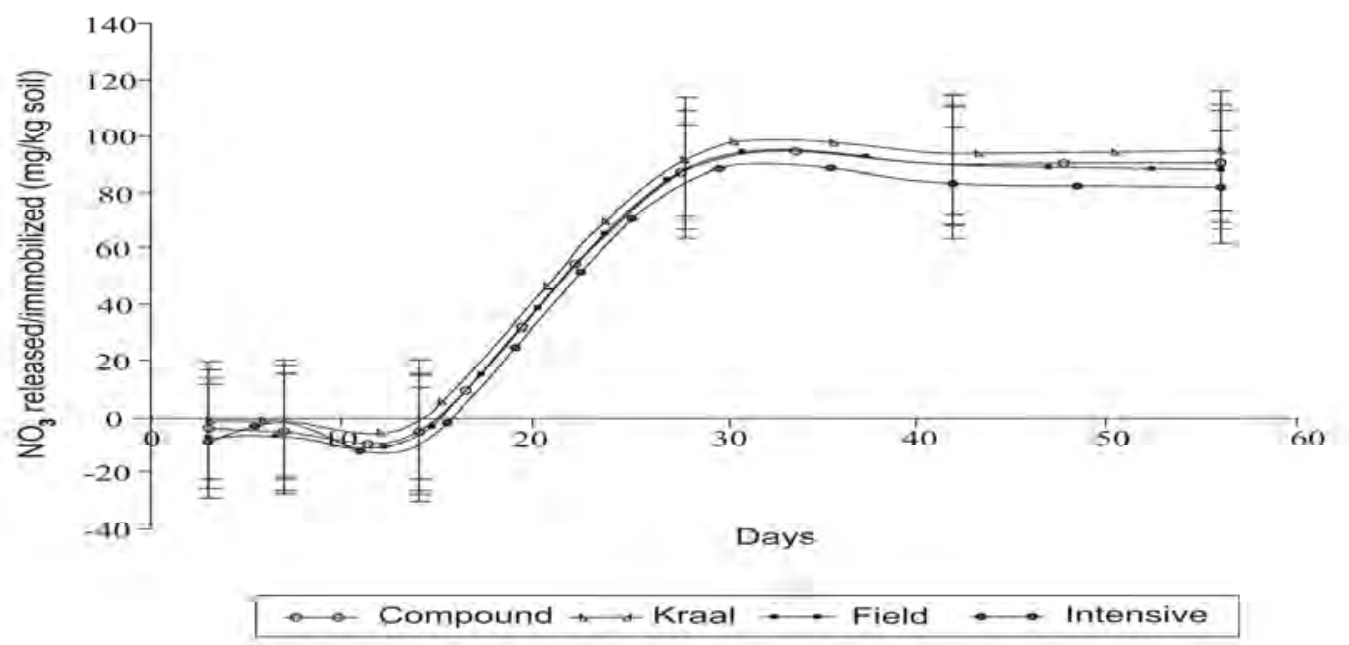

Figure 2. Amount of $\mathrm{NO}_{3}$ remaining at various stages of incubation. Bars indicate $S E D$ at $p=0.05$

The pattern of $\mathrm{N}$ release from manure of the different management systems in this study was similar irrespective of the $\mathrm{C}: \mathrm{N}$ ratios (Table 2 and Fig 3). This agrees with the findings of
Heinrich, (2009) and Nyamangara et al.,(1999), and implies that $\mathrm{C}: \mathrm{N}$ ratio of manure unlike that of plant residues is not a suitable parameter for predicting $\mathrm{N}$ mineralization of manures.

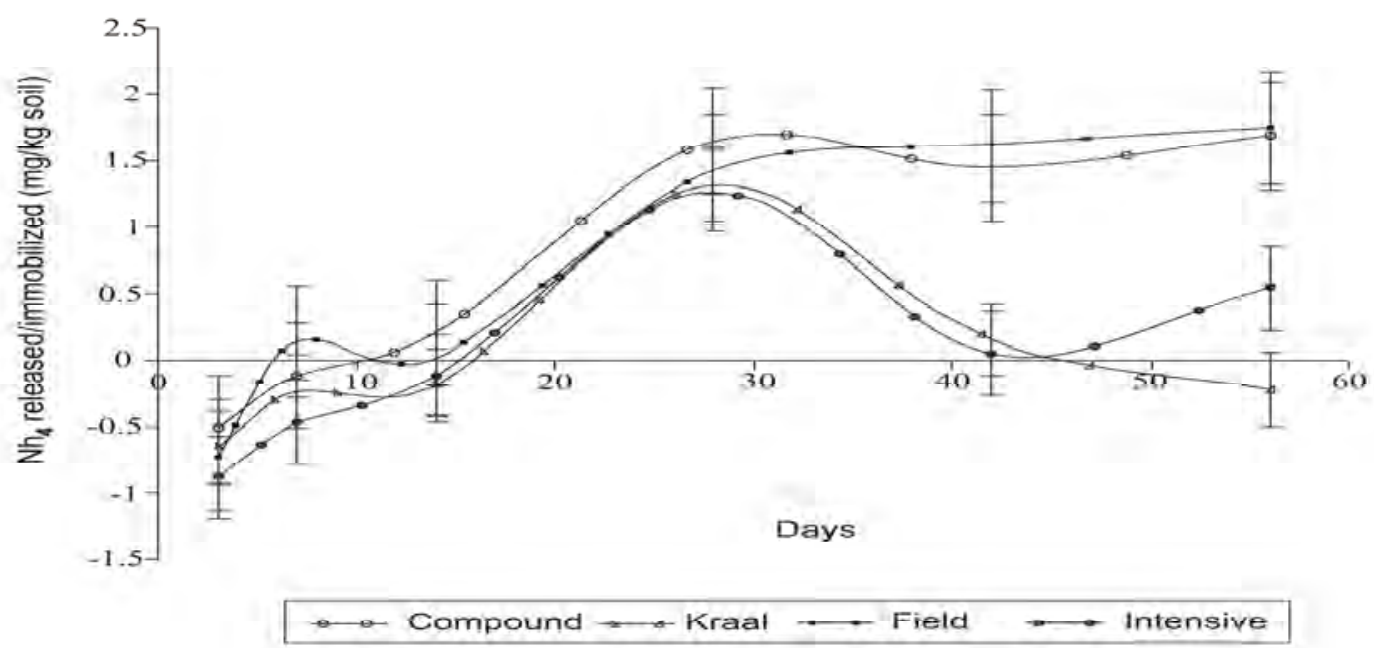

Figure 3. Nitrogen release patterns of different cowdung materials. Bars indicate SED at $p=0.05$

The pattern of $\mathrm{CO}_{2}-\mathrm{C}$ release was almost linear (Figure 4) and showed that $\mathrm{CO}_{2}-\mathrm{C}$ was mineralized throughout the eight weeks of incubation, similar to that observed by Mtambanegwe and Mapfumo (2004). 


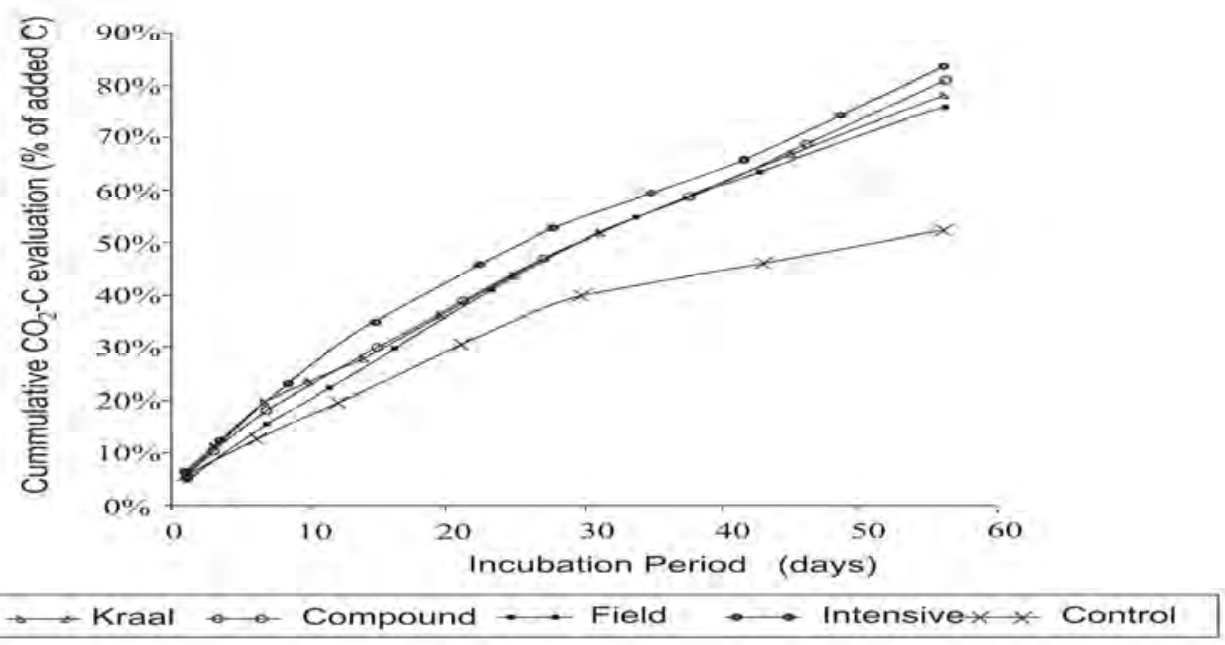

Figure 4. $\mathrm{CO}_{2}$ release patterns of different cowdung materials.

Mineralization of $\mathrm{CO}_{2}-\mathrm{C}$ throughout the incubation period is suggestive that manure usage has the potential of elevating atmospheric concentration of carbon dioxide that contributes to green house effect. Since manure is usually surface-broadcast or incorporated to a shallow depth of fields, information regarding decomposition and nutrient mineralization in manures at the soil surface is needed, in order to maximize their usage.

\section{CONCLUSIONS}

Cattle rearing by farmers in the Upper East region of Ghana is an enterprise that serves to accumulate wealth and provide sources of soil organic inputs for crop production. The benefits of cattle manure to farmers are through two basic mechanisms. Grazing cattle deposit their waste products into the soil as they feed. Alternatively cattle are periodically or permanently placed into stalls to facilitate recovery of manure. The study showed that cattle manure obtained from farmers' fields contain appreciable quantities of nutrients which suggest that their application to soil could improve nutrient availability to crop plants, however their management was found to be poor. This impact negatively on the fertilizer value and nutrient release patterns, suggesting the need to improve the quality by composting or addition of mineral fertilizer to balance crop nutritional requirements for realistic crop yield

\section{ACKNOWLEDGEMENT}

This research was funded by the United $\mathrm{Na}-$ tions University's Institute for Natural Resources in Africa (UNU/INRA).

\section{REFERENCES}

Anderson, J. M. and Ingram, J. S. I. (1993). Tropical Soil Biology and Fertility. Handbook of Methods. CAB International, Wallingford.

Arcia, F. J., Kauffman, J. H., Chang, R. and Marin, R. (1995). Cuba: Cracking heavy clay reference soils (Vertisols). Instituto Nacional de Investigaciones de la cana de Azucar, Habana and International Soil Reference and Information Centre, Wageningen.

Bremner, S. M. and Keeney, D. R. (1965). Steam distillation methods for determination of ammonium nitrate and ni- 
trite. Analytical Chemical Acta, 32: 485-495.

Constantinides, M. and Fownes, J. H. (1994). Nitrogen mineralisation from leaves and litter of tropical plants: relation ship to nitrogen, lignin and soluble polyphenol concentrations. Soil Biology and Biochemistry, 26: 49-55.

FAO (1984). Fertilizer and plant nutrition guide. FAO fertilizer bulletin 9 . FAO, Rome.

Fauci, M. F. and Dick, R. P. (1994). Plant response to organic amendments and decreasing inorganic nitrogen rates in soils from a long term experiment. Soil Science Society of America Journal, 58: 134-138.

Gee, G. W. and Bauder, J. W. (1986). Particle size analysis. Methods of Soil Analysis, Part 1. Physical and Mineralogical Methods. In A. Kulte (Ed.), Agronomy Monograph No. 9. American Society of Agronomy and Soil Science Society of America, Madison, Wisconsin. Analytical Issues for Frame work Development, IBSRAM, Bang kok, Thailand.

Giller, K. E., Witter, E. Corbeels, M. and Tit tonel, P. (2009). Conservation Agriculture and smallholder farming in Africa: The heretics' view. Field Crops Research (In Press).

Giller, K. E. (1999). Nitrogen mineralization: leaching tube protocol. Combined Inorganic-Organic Nutrient Sources: Experimental Protocols for TSBFAfNet, SoilFertNet and SWNM. In P. Mutuo and C. Palm (Ed), Tropical Soil Biology and Fertility, Nairobi, Kenya. pp. 17-19.

Giller, K. E., Cadisch, G., Ehaliotis, C., Adams, E., Sakala, W.D. and Mafongoya, P.
L. (1997). Building soil nitrogen capital in Africa. Replenishing Soil Fertility in Africa. In R. J. Buresh, P.A. Sanchez and F. Calhoun (Ed.), Soil Science Society of America, Special Publication 51, ASA, CSSA, SSSA, Madison, Wisconsin. pp. 151192.

Heinrich, A. L. (2009). Nitrogen fertilizer value of solid and liquid dairy wastes produced in California's San Joaquin Valley. M.S. thesis. Soils \& Biogeochemistry. University of California, Davis. pp 1-139.

Janssen, B. H. (1993). Integrated nutrient management: The use of organic and mineral fertilizers. The role of Plant Nutrients for Sustainable Food Crop Production in Sub-Saharan Africa. In $\mathrm{H}$. van Rueler and W.H. Prins (Ed). Pp. 85-105. Ponsen and Looijen Wageningen, The Netherlands.

Landen, J. R. (1991). Booker tropical soil manual. A handbook for soil survey and agricultural land evaluation in the tropics and subtropics, Longman Group, England, UK, p.79.

Macmillan (2001). Unimax Macmillan Senior Secondary Atlas. S. Nabila (Ed).

Mando, A., Ouattara, B., Somado, A. E., Wwopereis, M. C. S., Stoosnijder, L. and Breman, H. (2005). Long term effects of fallow, tillage and manure application on soil organic matter and nitrogen fractions and on sorghum yield under Sudano-Sahelian conditions. Soil Use Manage, 21: 25 - 31.

MoFA. (2001). Agriculture in Ghana, Fact and Figures. Statistics, Research and Information Directorate (SRID), Ministry of Food and Agriculture, Ghana. 
Mtambanengwe, F., Mapfumo, P. and Kirchmann, H. (2004). Decomposition of organic matter in soil as influenced by texture and pore size distribution. Managing Nutrient Cycles to Sustain Soil Fertility in sub-Saharan Africa. In A. Bationo (Ed), pp. 261-275. Academy Science Publishers in association with the Tropical Soil Biology and Fertility Institute of CIAT, Nairobi Kenya

Mugwira, L. M. and Mukurumbira, L. M. (1984). Comparative effectiveness of manure from communal areas and commercial feedlots as plant nutrient sources. Zimbabwe Agricultural Journal, 81:241-250.

Nhamo, N., Murwira, H. K. and Giller, K. E. (2004). The relationship between nitrogen minerlization patterns and quality indices of cattle manures from different small holders farming areas of Zimbabwe. Managing Nutrient cycles to Sustain Soil Fertility in Sub-Saharan Africa. In A. Bationo (Ed), Acadamy of Science Publishers, TSBF-CIAT, Nairobi, Kenya. pp. 299-315.

Nyamangara, J., Piha, M. I. and Kirchmann, H. (1999). Interactions of aerobically decomposed manure and nitrogen fertilizer applied to soil. Nutrient Cycling and Agroecosystem, 54: 183-188.

Palm, C.A., Gachengo, C.N., Delve, R.J., Cadisch, G. and Giller, K.E. (2001). Organic inputs for soil fertility management in tropical agroecosystems: application of an organic resource database. Agriculture Ecosystem and
Environment, 83: 27-42.

Palm, C.A., Myers, R.J.K. and Nandwa, S.M. (1997). Combined use of organic and inorganic nutrient sources for soil fertility maintenance and replenishment. Replenishing Soil Fertility in Africa. In R.J. Buresh and P.A. Sanchez (Ed), SSSA Special Publication 51. SSSA, Madison, WI, USA. pp. 193-21.

Parkinson, J. A. and Allen, S. E. (1975). A wet oxidation procedure suitable for the determination of nitrogen and mineral nutrients in biological materials. Communications in Soil Science and Plant Analysis, 6: 1-11.

Pettygrove, G. S. and Heinrich, A. L. (2009). Manure nitrogen mineralization. Manure Technical Bulletin Series. http:// manuremanagement.ecdavis.edu.

Stotzky, G. (1965). Microbial respiration. Methods of Soil Analysis. Vol. 2.b. In C.A. Black (Ed), American Society of Agronomy, Monograph No.9, Madison, USA. pp.1550-1572

Sys, C. E., Van Ranst Debaveye, J. and Beer naert, F. (1993). Land Evaluation Part III, Crop Requirements. Agricultural Publication No. 7. General Administration of Development Cooperation Brussels, Belgium.

Walkley, A. and Black, I. A. (1934). An examination of the Degtijareff method for determining soil organic matter and a proposed modification of the chromic and titration method. Soil Science, 37:29-38. 